\title{
Paleoecology of some Upper Cretaceous Formations from Selected Wells Northwest and Middle Iraq
}

\author{
Ibrahim Y. Al-Shareefi \\ Department of Geology \\ College of Science \\ Mosul University
}

\author{
Saleh K. Khalaf \\ Department of Geology \\ College of Science \\ Mosul University
}

\author{
Marwan A. Al-Eisa \\ Department of Geology \\ North Oil Company \\ Kirkuk
}

(Received 7/10/2009, Accepted 18/3/2010)

\begin{abstract}
On the basis of the biocontents, lithological features and analysis of the microfacies, an attempt is made to establish the nature of paleoecology and depositional environments of some Upper Cretaceous formations from northwest and middle Iraq , of which the successions are represented by the formations from the oldest to the youngest are Khasib, Tanuma, Sa'di, Mushorah, Hartha and Shiranish.

A wide spectrum of environmental types distributed between deep and shallow marine environments. The implication of paleoecological interpretations for different Ostrscode species and other fossils recorded in the studied sections highlights the strong correlation between the environmental parameters in particular the depths and the lifestyle of these organisms including specific morphologies and faunal abundance.In addition to that from palaeocological point view the identified biocontents represent a southern shelf tythes fauna.

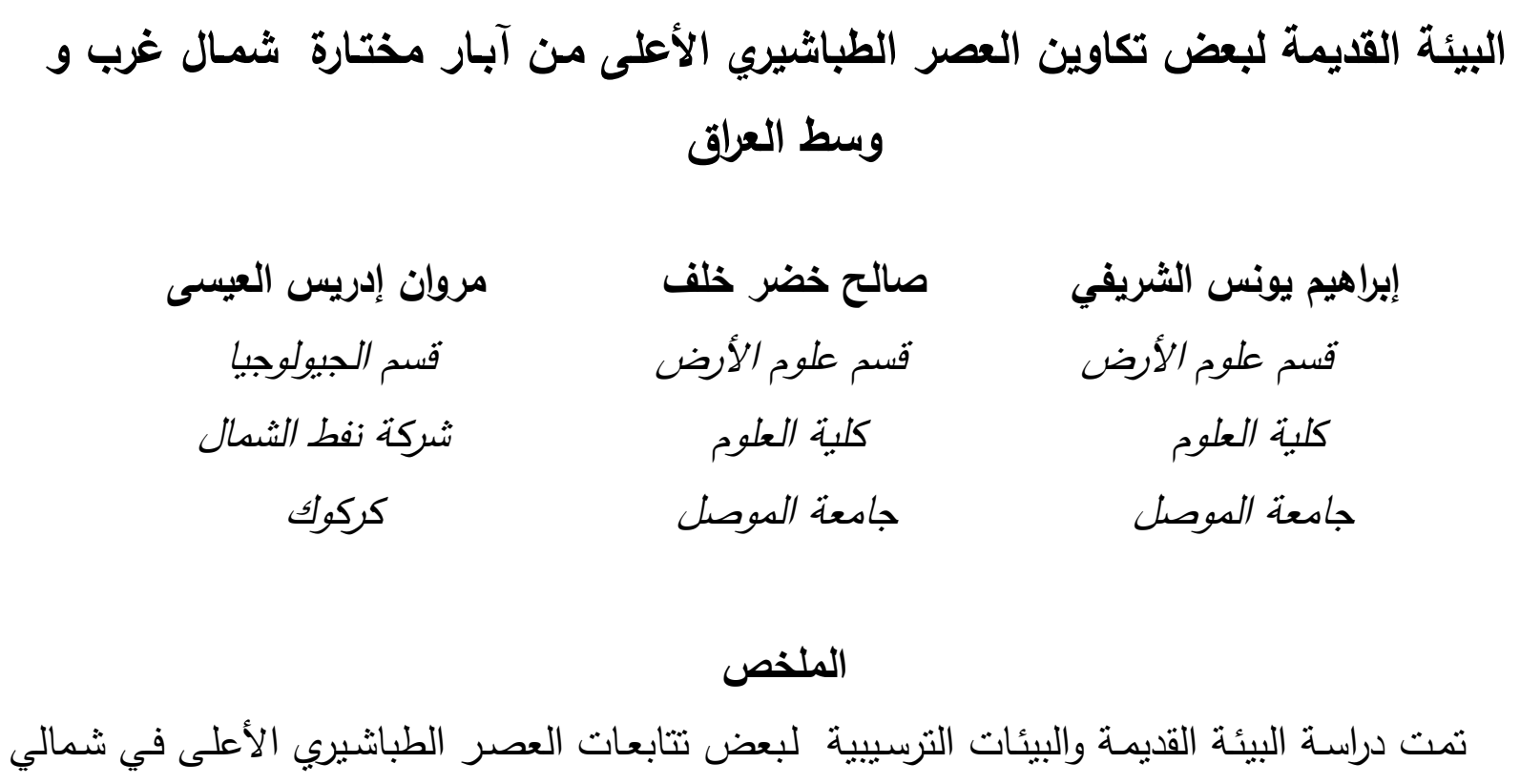




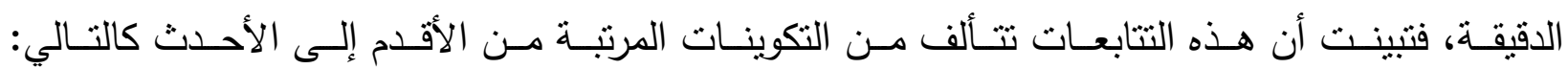
الخصيب، التتومة، السعدي، المشورة، الحارثة و شرانش.





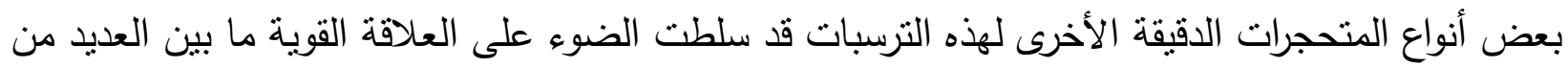

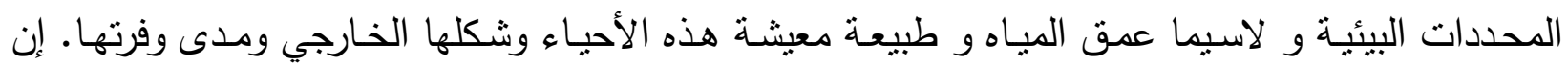
دراسة المتحجرات الدقيقة في هذه الدراسة قد أظهرت عائديتها إلى المنطقة الجنوبية من التيشس.

\section{INTRODUCTION}

A total of 453 core and cutting samples were obtained from sections of Upper Cretaceous successions from four wells $(\boldsymbol{A}, \boldsymbol{B}, \boldsymbol{C}$ and $\boldsymbol{D})$ within trend extended to the west Tigris river in the northwest and middle parts of Iraq (Fig. 1) .These sections comprised six formations from older towards the younger are: Khasib, Tanuma, Sa'di, Mushorah, Hartha and Shiranish Formations. In this respect, (Figs. 2, 3, 4 and 5) shows the stratigraphic sections of these formations in the studied wells. Geographically, the studied area is located Northwest and Middle Iraq approximately between latitude $34^{\circ} 20^{\prime}-35^{\circ} 50^{\prime} \mathrm{N}$ and longitude $42^{\circ} 50^{\prime}-43^{\circ}$ $40^{\prime} \mathrm{E}$. Geologically, the investigated area belongs to the unstable shelf of Iraq within Hamrin-Makhul subzone and Tigris subzone (Buday and Jassim, 1987).

The main aim of the present study to through the light on the paleoecology and the depositional environments were inferred for the studied formations depending on lithological features and analysis of the microfacies in addition to the most biocontents including Ostracode, Foraminifera (Planktonic and Benthonic), Algae (Rhodophyta and Chlorophyta), Bryozoa, Echinoderms debris, Calcisphere, Pelecypode and Harteadae.

Palaeoecology is the study of interaction of organisms with one another and with the physical environment in the geological past (Dodd and Stanton, 1981). The basic data of palaeoecology are the fossils, adequately identified and correctly positioned within the stratigraphic framework.

Generally, most authors accepted that sessile fossils benthos are the best ecological indicators. Therefore, the Ostracode taxa ( plates 1and 2 ) are frequently used as a tool for prediction and reconstruction of palaeoenvironments because they are determined by a variety of environmental parameters which in turn may be linked to prevailing climatic conditions (Frogley et al., 2002). 
Paleoecology of Some Upper Cretaceous Formations

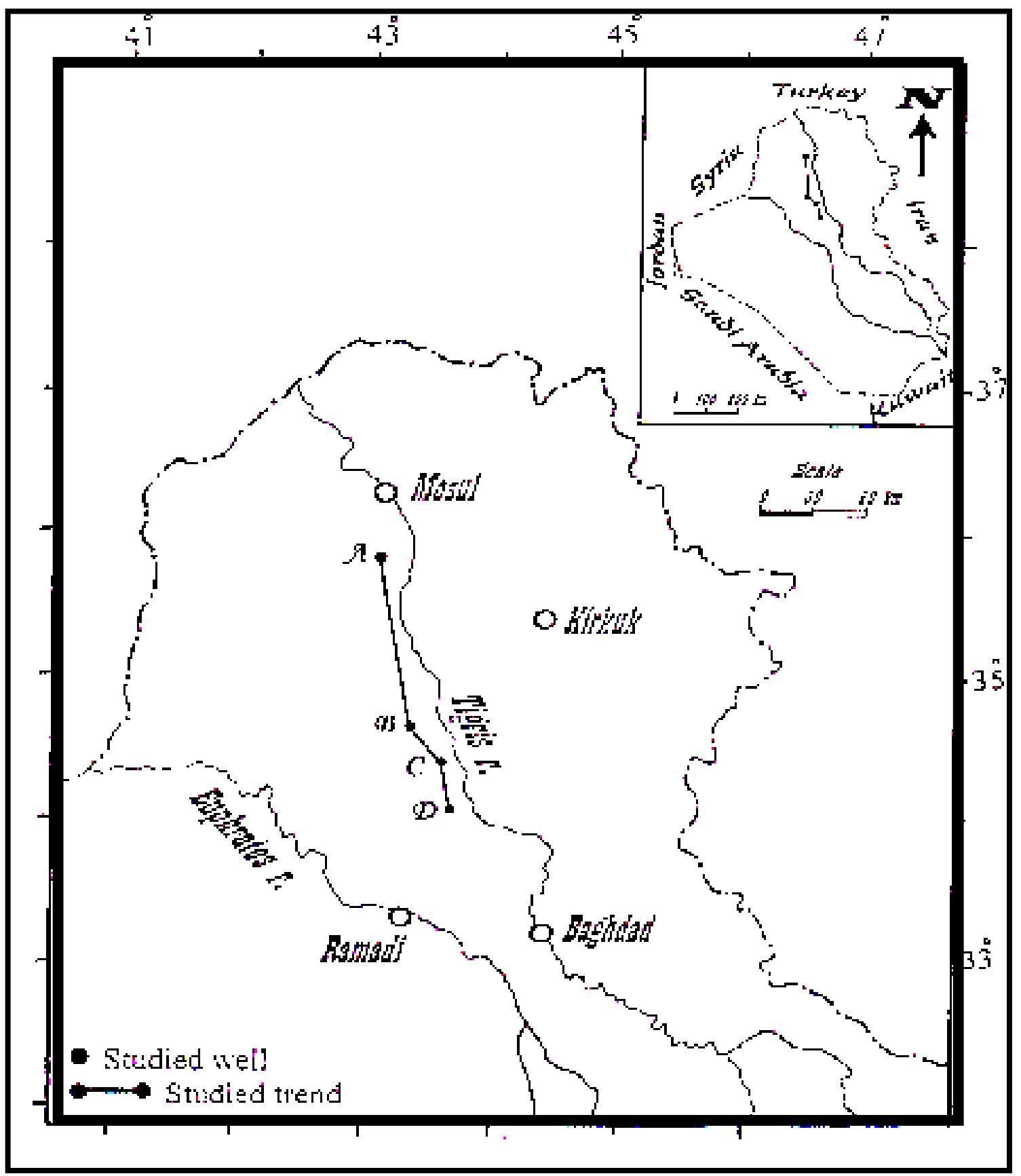

Fig. 1: Location map

\begin{tabular}{|c|c|c|c|c|c|c|}
\hline 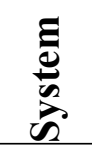 & :气 & 总 & 竞司 & 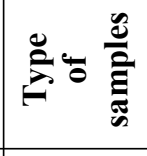 & Formation & Lithology \\
\hline & & $\stackrel{\Xi}{\sigma}$ & $-421-$ & \begin{tabular}{|c|} 
cu 1-8 \\
cu 9-13
\end{tabular} & & 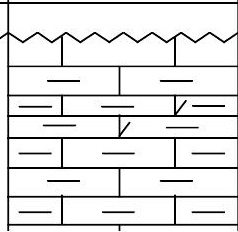 \\
\hline
\end{tabular}


Ibrahim Y. Al-Shareefi et al.,

\begin{tabular}{|c|c|c|c|c|c|c|c|}
\hline 离 & & $\overleftarrow{5}$ & & 离気 & $\underline{\text { cu }}^{\frac{0}{\tilde{c}}}$ & Formation & Lithology \\
\hline & & $\sum$ & ral & $\begin{array}{l}-830- \\
-838-\end{array}$ & $\begin{array}{ll}1 & 1 \\
2 & 1 \\
3 & 1 \\
4 & 1\end{array}$ & \begin{tabular}{|c|} 
Jaddala \\
Shiranish \\
$\mathbf{1}$ \\
\end{tabular} & 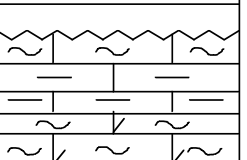 \\
\hline
\end{tabular}


Paleoecology of Some Upper Cretaceous Formations..........

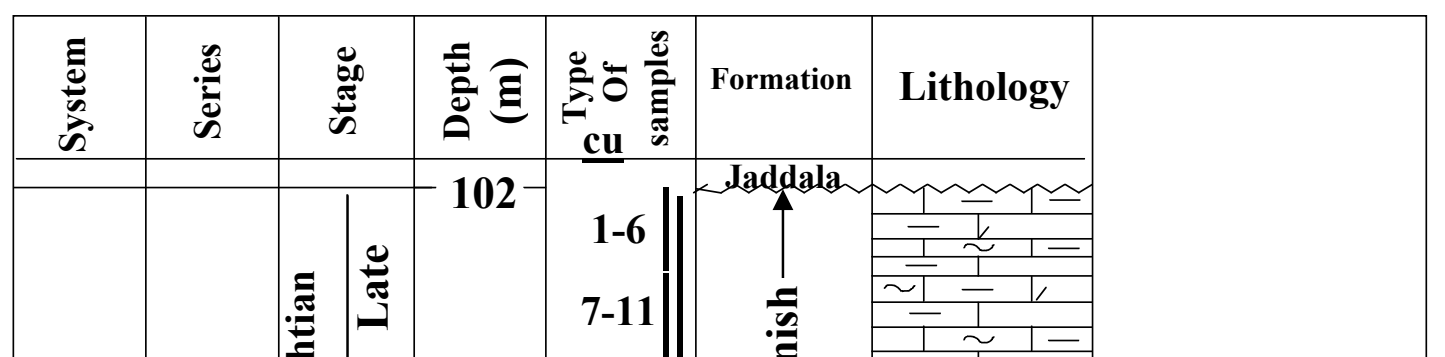


Ibrahim Y. Al-Shareefi et al., 
Paleoecology of Some Upper Cretaceous Formations.........

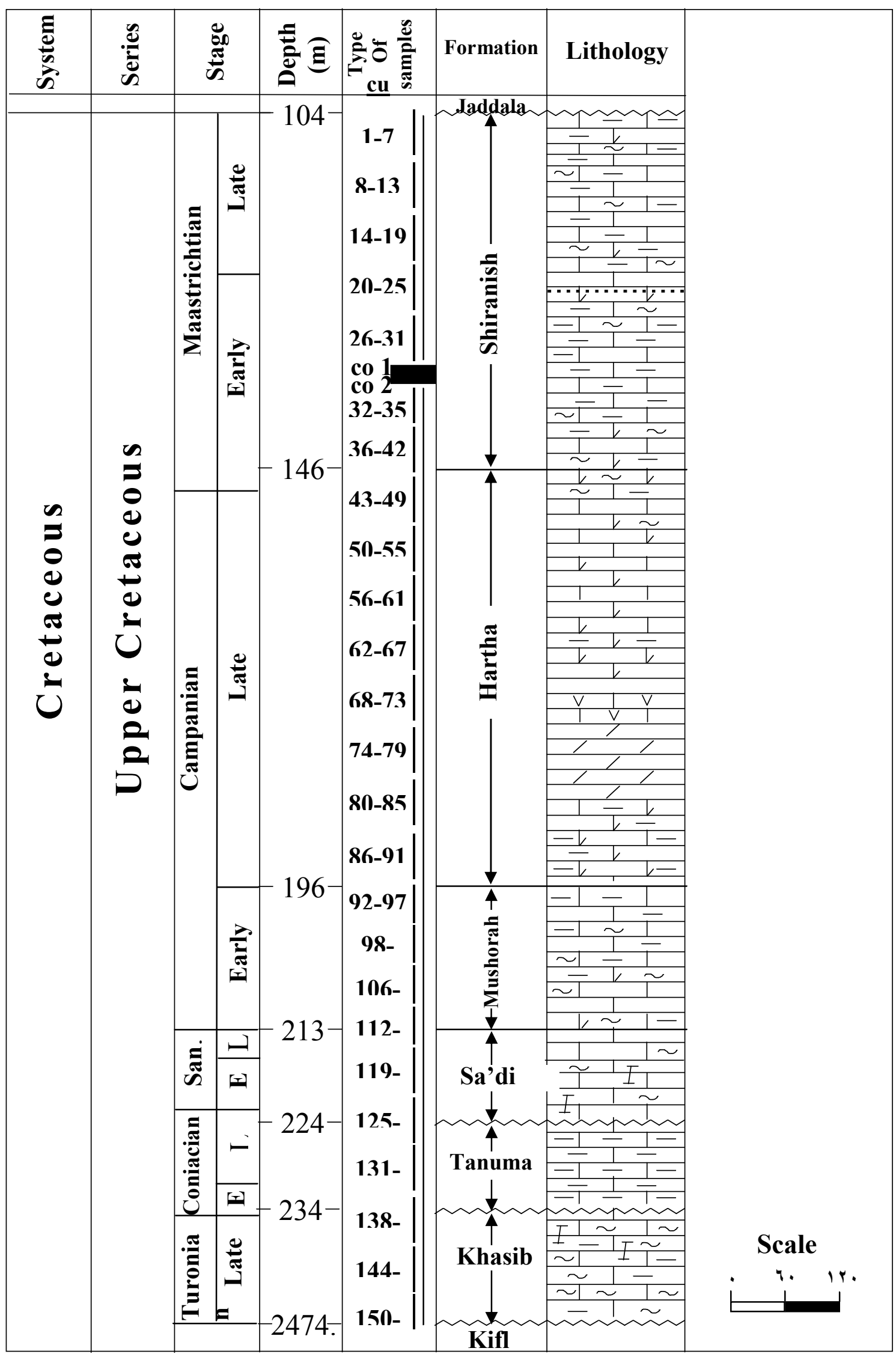

Fig.5 : Stratigraphic section of upper Cretaceous formations in well $\boldsymbol{D}$ According to Monostori (1985) the primary aim of the environmental studies by using Ostracode is to determine the association indicating former environmental 
types. The distribution of the Ostracode species is largely determined by variety of environmental parameters such as water depth, temperature, solute composition substrate, turbulence, and total dissolved solids (Monostori, 1985; Frogley et al., 2002). The organism survival is lower at higher temperature and at higher salinity (Van Doninck et al., 2002). The depth of the basins is one of the most important factors affecting the distribution of organisms within the different environments. Therefore, many authors are interested in specific subdivisions for basins such as Puri et al., 1969; Van Morkhoven, 1972; Ducasse and peypouqet, 1979; Sliter, 1985; Koutsoukos and Hart, 1990 and Kuznetsova and Dobrova, 1997.

In the present study, the subdivision of marine environments from Sliter, 1985; Koutsoukos and Hart, 1990 (Fig. 6) was found more comprehensive and specific than the former subdivision. The applications of Ostracode as an indicator for paleobathymatery have been emerged through the basic following principles:

\section{1- Index genera}

Ostracode occure in both marine and non marine environments and are known from nearly all the types of aquatic habitats: littoral (marginal vegetation), lake benthos, streams and interstitial waters, fresh to highly saline waters in salinities of up to three times sea water) and in temporary environment (Martens, 2001).

In spite of the wide range of Ostracode environmental occurrence, many genera are regarded as an indicators for certain depths (Babinot and Colin, 1983). Depth range data show that some species have broad ranges and others narrow ranges and there are specific depths at which each species is more abundant (Park et al., 2000).

The change in the depth of water causes to dissimilarity in several morphological features which often can be used as a proof on paleobathymatery. Nevertheless its always very difficult to decide whether one is dealing with species when only morphological features are changed.

According to Elfson (1941) many genera are regarded as a characteristic of deep water environments such as Krithe, Argilloecia and Paracypris while others genera are regarded as a characteristic of the shallow water environments such as Xestoleberis and Loxoconcha. Because the deep water is relatively cold, so the deep water taxa called Psychrospheric while the shallow water taxa caled Thermospheric (Benson, 1984).

Van Morkhoven (1962) has mentioned that the smooth carapace and the absence of eye tubercles are characteristic for the deep water taxa.

Benson (1972) suggested that the taxa with smooth carapace and absence of the lateral spines are discriminating for the outer shelf - middle slope environment such as Bythocypris, Pontocyprella and Krithe.

The shallow water taxa also are recognized by the development of eye tubercle, strong ornamentation and high calcification due to the abundance in 
Paleoecology of Some Upper Cretaceous Formations..........

nutrition and oxygen and as a kind of adaptation for the high energy environments (Benson, 1984).

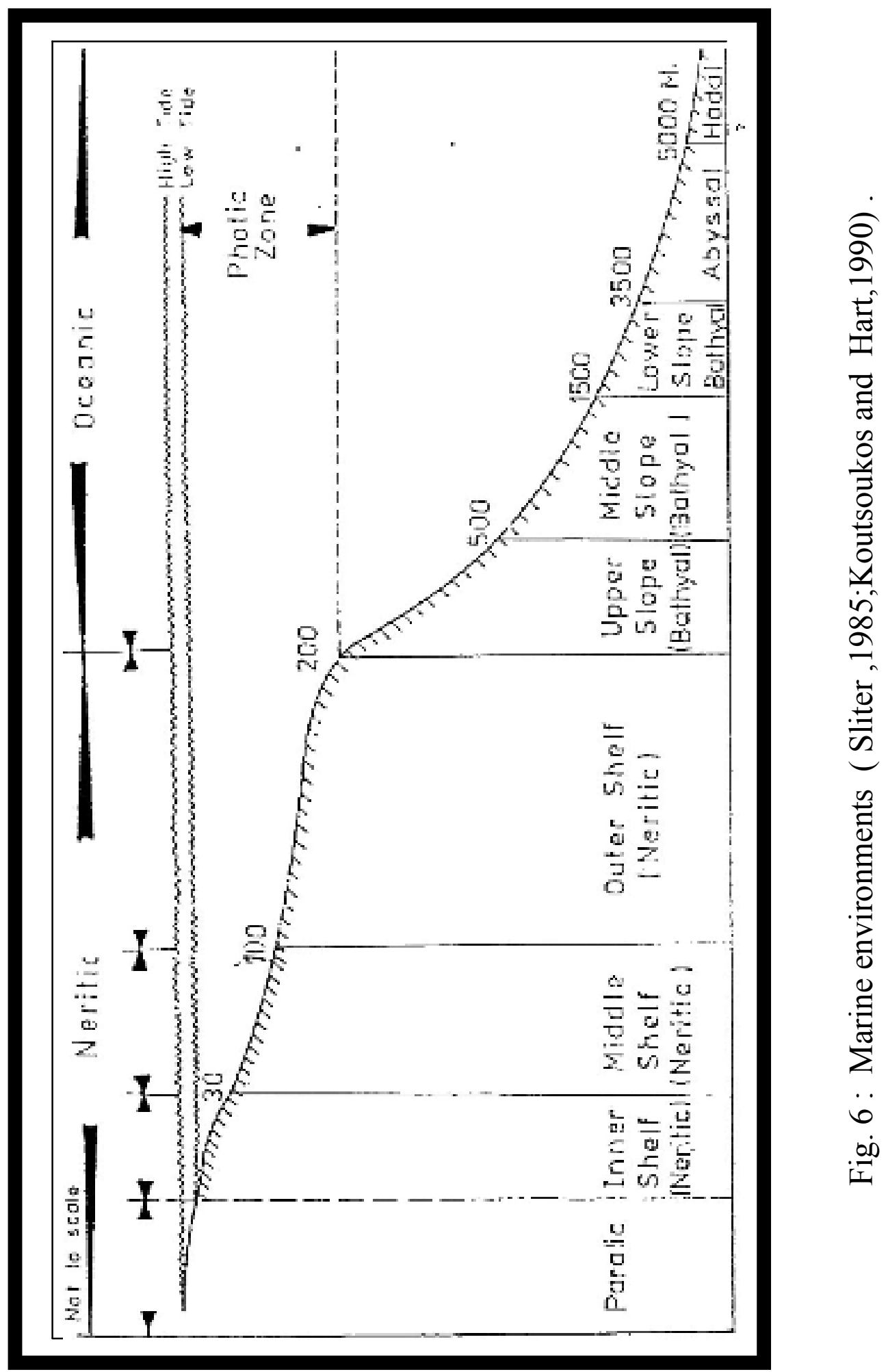

\section{2- Index Ostracode assemblages}


The association of more than one taxon within specific assemblages is very important for concluding and interpretation of the paleoenvironments. These taxa must share in at least one feature. Many previous authors had suggested a various assemblages as an indicators on depth (Fig. 7). The paleoecology and the environment of deposition in the studied formations have been determined mainly by using the characteristic Ostracode genera in addition to other fauna and microfacies (Fig. 8). On the basis of the above principles and the observed microfacies, the paleoecology of the studied formations have been outlined below:

\section{Khasib Formation}

A characteristic species for this formation are: Cytherella, Metacytheropteron, Pontocyprella, Schuleridea and Parakrithe.

The high abundance of Cytherella associated with Metacytheropteron which can be distinguished obviously in the lower parts of the formation in the well $\boldsymbol{B}$ solely and also the occurrence of Cytherella associated with Schuleridea in the upper parts of the most studied sections indicates shallow marine environment (Rosenfeld et al., 1988; Maltz et al., 1985 ) or sublittoral environment (Rosenfeld and Raab, 1983).

The presence of the assemblage Cytherlla and Pontocyprella in several positions in the lower and middle parts of this formation indicates outer shelf environment (Zarraga and Lazzaro, 1990). Also presence of Parakrithe in the lower and middle parts of the formation and the high proportion of individuals indicates deep water marine environment (Van Morkhoven, 1963)

The presence of the planktonic foraminifera Helvetoglobotruncana helvitica indicates deep marine (upper slope) (Sliter, 1989) while the presence of Marginotruncana indicates continental shelf environment (middle - outer shelf) (Sliter and leckei, 1993). Furthermore the occurrence of Hedbergella and Heterohelix which indicates continental shelf (outer shelf) environment (Sliter, 1972).In addition, different groups of faunas such as algae, bryozoa, calcisphere, sponge spicules, echinoderms and pelecypodes are present within the dominant grainstone facies in the upper parts of the formation indicates shallow water environment.

Whereas, all the algae restricted in shallow environments enough for photosynthesis (Dodd and Stanton, 1981) and the bryozoa are most abundant and diverse on the depth 20-80 m. (cuffey, 1977).

From all the indications presented above the recognized environments of the upper parts of Khasib Formation differ from the ideal environment for deposition of this formation 
Paleoecology of Some Upper Cretaceous Formations..........

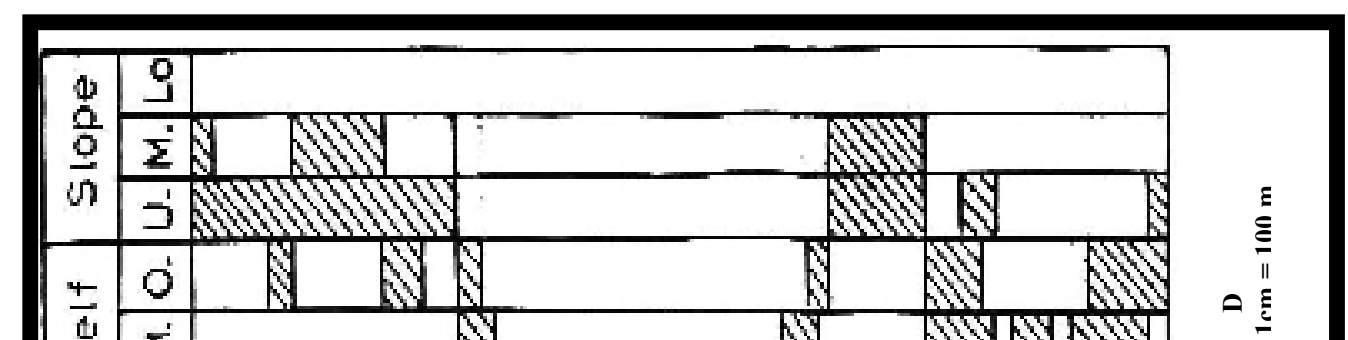


Ibrahim Y. Al-Shareefi et al.,

(subbasinal and basin margin environment). During the environmental fluctuations, however, species are subjected to different circumstances and other aspects of specific Tolerance which can then become important (Martens, 2002). 
The alteration in lithofacies in the upper parts in this formation is due to the changes in the environmental conditions caused by the changing in from mudstone and wackstone to grainstone microfacies. It is also followed by the effectiveness of the late diagenesis and the unconformity at the end of Turonian age which conform with the postulates of (Haq et al., 1987). The global environmental change suggests a large-scale, single phenomenon, it is actually due to the effects of many forms of disturbances of different types, mode of action, and ecological out comes (Lacke et al., 2000).

It is also important to mention that the whole previous effectual factors caused a great improvements in the petrographical features of this formation including porosity and permeability which makes this formation as one of the most important reservoir in the country.

The conformability of the distinguished facies from the present study with SMF types 2, 3, 6, 8, 9, 12 deposited within the FZ 1, 2, 3, 4, 6, 7 with model of (Wilson,1975) modified by (Flügel, 1982) suggested a widespread distribution of basinal and basin margin environments in particular in the lower and mid parts of the formation with the foreslope, winnowed platform and open platform as a depositional environments in the upper parts.

\section{Tanuma Formation}

This formation is characterized by the occurrence of Cytherella, Bairdia, Brachycythere, Schuleridea, Ovocytheridea, Parakrithe, veenia and Xestoleberis.

The presence of large and smooth Cytherella species associated with Pontocyprella in the upper parts of this formation in the well $\boldsymbol{A}$ indicates outer shelf or outer platform (Zarraga and Lazzaro, 1990). The dominance of the assemblage of Cytherella, Bairdia and Schuleridea in particular in the upper parts of the section of the well $\boldsymbol{C}$ with the obviously appearance of the association Cytherella, Bairdia and Veenia in all the studied sections indicates a warm shallow marine (Neale, 1977) or (sublittoral) Al- Abdul- Razzaq, 1983.

The genus Xestoleberis occur sporadically in the section of the wells $\boldsymbol{C}$ and $\boldsymbol{D}$ suggesting littoral to epi-neritic even brackish water conditions (Van Morkhoven, 1963). The accompanying of Cytherella and Veenia in particular in the upper parts in the well $\boldsymbol{A}$ indicates open marine moderately deep neritic conditions (Van Morkhoven, 1963). Also the presence of Ovocytheridea with Xestoleberis in some levels in the upper parts of the formation in the well $\boldsymbol{A}$ indicates littoral environment (Shahin, 1988).

From the other faunas, the presence of , Heterohelix, Globigerinelloides, Hedbergella in the upper parts of the formation in the wells $\boldsymbol{A}$ and $\boldsymbol{B}$ indicates inner - middle Shelf (Koutsoukos et. al., 1991) and shallow marine (Sliter and Leckei, 1993). Also the occurrence of miliolide species in this formation in the middle parts in the wells $\boldsymbol{A}$ and $\boldsymbol{C}$, upper parts in the well $\boldsymbol{D}$ and lower parts in the well $\boldsymbol{B}$ indicates lagoon (Brasier, 1980). 
The dwindling in the number of ostracode individuals in comparison with the other studied formations is the result of very low oxygen levels in this environment. According to (Emery and Myers, 1996) the anoxic or dysareobic conditions are evidence of restricted vertical circulation environment which are due to the accumulation of organic materials after the death of organisms. In addition, the bacterial oxidization of planktonic microorganisms in the Epiric seas or small basins result in anoxic environments. Generally, three basic reasons are discussed and listed by(Emery and Myers, 1996) result in anoxia:

1- Hereditary topography of the basin as a result to the dissolution of carbonate rocks during the regression and the denudation of anoxia below the surface.

2- Tectonic episodes in particular the differential subsidence before and during the sedimentation conduce to formation an isolated basins which the restricted circulation results in anoxia.

3- Transgression in low- productivity carbonate systems results in sediment starvation of the outer shelf deep ramp and deposition is dominated by pelagic carbonate.

Therefore this will explain the obviously appearance of sponge spicules, Inoceramus prisms, calcisphere and richness in the organic material a composed by decreasing diversity and the stunting in both of ostracode and foraminifera which are recorded previously from anoxic environments. The clear presence of pyrite in this formation has been regarded as a result of reduction conditions (Hammoudi,1995).

The conformability of the distinguishing facies from the present study with SMF types 2, 3, 4, 8, 9 deposited within the FZ 3, 4, 7 with model of (Wilson,1975) modified by (Flügel,1982) suggested fore slope, shelf edges, warm shallow water, lagoons, very restricted bays and ponds .

Al-Hamdani (1986) suggested the shallow marine (inner shelf) environment for this formation. Middle shelf with fluctuation toward the inner and outer shelf with lagoon environment is also proposed by Hammoudi (1995) for the deposition of this formation on the basis of the presence of planktonic and benthonic foraminifera.

\section{Sa'di Formation}

A characteristic species for this formation are Cytherella, Dumontina, Brachycythere, Ovocytheredia, and Shuleridea. Generally, the ostracode fauna of this formation is low in abundance and diversity. The occurrence of Brachycythere and Ovocytheridea in particular in the middle parts in the sections of the wells $\boldsymbol{A}$, $\boldsymbol{B}$ and $\boldsymbol{D}$ and upper parts in the section of the well $\boldsymbol{C}$ indicates marine, shelf and slope environments (Van Morkhoven, 1963). The presence of Cytherella and Shuleridea in different positions within this formation in all the studied sections indicates shallow marine (Neal, 1977).

The planktonic foraminifera, in particular, Globotruncana lapparanti and Globotruncana stuartiformis are present in this formation but not abundantly 
which indicates tropical or subtropical environments (Bandy, 1967). These species occur mainly in the uppermost of the lower parts and middle parts of the formation in the wells $\boldsymbol{A}, \boldsymbol{B}$ and $\boldsymbol{D}$ and also occur but limited and sporadically at the bottom of the formation in the wells $\boldsymbol{A}$ and $\boldsymbol{D}$ which reflect the middle-outer shelf to upper slope (Slilter, 1972). The high presence of benthonic foraminifera such as Rotalia skourences; Gavilinella; Cibicides and Discorbis in association with green algae (Dissocladella undulata in particular in some places within the lower parts), sponge spicules, pelecypode ( Halobia remains and Inoceramus prisms ), bryozoa and echinoderms debris indicates shallow marine and inner shelf environments.

The conditions of deposition have fluctuated widely within this generalized broad transition from a relatively deep marine to shallow marine environments. According to Schön et al., 2000, if the endemic species can endure such drastic environmental changes, the high numbers of them is the result of hyperspecialization resulting in diversification.

The conformability of the distinguishing facies from the present study with SMF types 3, 8, 9 deposited within the FZ 1, 2, 3, 7 with the model of (Wilson, 1975) modified by (Flügel, 1982) suggested basinal, deep shelf margin and open lagoon.

\section{Mushorah Formation}

The ostracode fauna characteristic this formation are Cytherella; Bythocypris, Paracypris, Argilloecia, Abyssocypris, Brachycythere and Planileberis. The occurrence of Ostracode species such as Cytherella, Argilloecia and Bythocypris are characterized by the smooth and thin carapace which have an absence of both the strongly ornamented surface and the eye tubercle indicates deep marine environment (Van Morkhoven, 1972). The presence of Cytherella and Argilloecia in the lower and middle parts of the formation indicate marine environment with depth more than 200 m.(Van den Bold, 1966). According to( Puri et al., 1969) the majority of Paracypris occur in sublittoral regions. The above mentioned remark and the presence of Paracypris associated with Argilloecia in some places suggest a contact with the open sea (Reyment, 1980). Moreover the obvious occurrence of Cytherella associated with Argilloecia and Paracypris in the middle and upper part of the formation also indicate deep marine and open sea environments (Monostori, 1985).

A deep water environment is also proposed for the deposition of this formation on the basis of presence of planktonic foraminifera recognized by the present study. These planktonic foraminifera taxa are represented mainly by the species belonging to the genus Globotruncana such as Globotruncana angusticarinata; Globotruncana ventricosa and Globotruncana bulloides with accompaniment of calcisphere and Hartella indicates basin margin and slope environments. In addition, Heterohelix, Hedbergella and Rugoglobigerina are also 
present in the lower parts of the formation of the well $\boldsymbol{A}$ indicates shelf environment (Sliter, 1972).

However, the rarity of the paracypris, Argilloecia and Bythocypris in the middle parts and towards the upper parts of the formation with obviously occurrence of benthonic foraminifera (Rotalia, Sulcoperculina, Lenticulina and Lagena), algae (Permocalculus, Lithothamnium) and pelecepode (Halobia debris) indicates shallow water environments.

The conformability of SMF types 3 and 9 deposited within the FZ 1, 2, 3 with model of (Wilson, 1975) modified by (Flügel, 1982) suggested basin margin, deep water, fore slope and shallow water with open circulation.

\section{Hartha formation}

This formation characterized by the presence and occurrence of Occultocythereis, Paracyprideis, Xestoleberis, Planileberis, Cytherella, Bairdia, Paracypris, Abyssocypris, Bythocypris, Pontocyprella and Propontocypris.

The taxa Cytherella and Bairdia are of considerable interest and importance in the fauna range over a wide range of depth and they are present from shallow, even brackish environment, to bathyal and even abyssal depths. These taxa certainly flourished or be rather limited in their developments in each environment but are not restricted to it.

However, their adaptation have been reflected mainly in the strongly sculpture of the carapace surface. Dissimilarity between morphological and genetic rates of changes thus reflect deviation from the gradual model (Martens et al., 2000). In this formation, these taxa present with high incidence of punctate forms and thick shelled which indicated inner shelf environment (Babinot and Colin, 1983). The presence of Occultocytheris in this formation indicates marine, mostly epi-neritic environment while the occurrence of Propontocypris indicate neritic environment (Van Morkhoven, 1963).

The occurrence of the assemblage Cytherella, Bairdia and Paracypris in different places within this formation indicates warm shallow marine (Neal, 1977) and sublittoral (Rosenfeld et al., 1988).

The association of Cytherella, Bairdia and Paracypridies which declines or even disappear in the middle parts of the formation, reappearing towards the top indicate sublittoral environment (Al- Abdul- Razzaq, 1983). The association of Cytherella, Bairdia and Pontocyprella in some positions within this formation in particular in the successions of the well $\boldsymbol{A}$ and $\boldsymbol{D}$ indicates middle shelf environment (Dingle, 1981).

In the upper part of the formation, the presence of some taxa characteristic of deep environment such as Pontocyprella, Bythocypris and Abyssocypris associated with those of broad range of depth tolerance such as Cytherella and Bairdia can refer to the deep parts in the shallow environment in particular in the uppermost 
part of the formation (Martens, 1994). It is also an indication for the starting of the transgression and the gradational connection with open sea.

The occurrence of some larger benthonic foraminifera particularly Orbitoides in high number of individuals suggested the warm shallow marine $(50-100 \mathrm{~m})$ or fore reef environment (Fourcade and Butterlin,1988) And shallow tropical to subtropical (Van Gorsel, 1978). Also the abundantly occurrence of rotalids in many positions in particular in the lower part of the formation in the well $\boldsymbol{A}$ indicate brackish water such as mentioned by Henkel (2002).

The obviously occurrence rate of Miliolid with conjugation by green algae in different positions within all the studied sections indicates the protected shelf or lagoon within inner shelf environments (Arnal, 1973).

On the other hand, the occurrence of Rudist debris, algae, bryozoa, sponge spicules in the middle of the formation of the well $\boldsymbol{A}$ indicate also shallow environment (Buchbinder, 1977) and fore-reef slope commonly in high energy (Flügel, 1982).

Generally, this formation seems to be having an ecological stability during the deposition restricted within the shallow environment. It is noteworthy to mention here that it is important to distinguish between geological and ecological stability: the former term deals with the continued persistence of a water body over long periods of time (more than one million years), whereas the later refers to environmental frames, either predictable (cyclic) or unpredictable (catastrophic) (Martens and Schön, 2000).

The conformability of the distinguishing facies from the present study with SMF 2, 3, 4, 6, 8, 9 types deposited within the FZ 2, 3, 4, 7 with model of (Wilson, 1975) modified by (Flügel, 1982) suggest open sea,deep shelf margin,fore slope and shlf lagoon.

Dolostone facies is also present in this formation within the mudstone microfacies in tow places from the middle parts of the well of $\boldsymbol{A}$ and in the lower parts of the well $D$.

\section{Shiranish Formation}

The Ostracode fauna characterizing this formation are Bairdia, Cytherella, Bythocypris, Paracypris, Pontocyprella, Propontocypris, Argilloecia, Abyssocypris, Paracyprideis, Schizocythere, Isohabrocythere, Bracgycythere, Krithe, Occultocythereis, Ordonia, Halcopocythere, Hornibrookella and Xestoleberis.

Van Morkhoven (1963) noted that Krithe one of the most common genera dominating outer shelf-bathyal environments and also mentioned that Argilloecia, Brachycythere, Bythocypris, Paracypris and Schizocythere indicators of deep marine environment and as such all recorded in the middle and upper parts of the formation. 
The genus Pontocyprella is restricted to open sea, basinal environments as indicated by (Colin et al., 1982) while the Bairdia is recognized from abyssal environment of recent sediments in the Mediterranean sea (Bonaduce et al., 1983). The presence of the assemblage Cytherella, Bairdia, Krithe and Paracypris in the middle and upper parts of the formation indicates outer shelf-bathyal environments (Dingle, 1981).

The occurrence of Krithe associated with Argilloecia, Bairdia, Cytherella and paracypris in the upper parts of the formation in all the studied sections indicates open sea (Monostori, 1982). The assemblage of Cytherella and Bairdia in many positions in the studied area indicates deep sea (Ishizaki and Kaiho, 1990; Warne, 1993). The presence of Argilloecia, Pontocyprella and Paracypris in the middle and lowermost of the upper parts of this formation in all the studied sections indicates partial connection with open sea environments (El-Waer, 1992).

The occurrence of Argilloecia, Bythocypris and Bairdia in the lower parts of formation in the well $\boldsymbol{B}$ indicates deep marine (about 100m) Harton and Droste (1988). (Van den Bold, 1971) recorded the taxa Cytherella and Argilloecia from the marine environment (More than 200m) and imply the same inference from the sporadically occurrence in different places in all the studied sections.

The presence of unkeeled planktonic foraminifera such as Globigerinilloides, Hedbergella and Heterohelix contemporary with rarity of the keeled forms in the upper parts of the formation in the well $\boldsymbol{B}$ and the middle parts in the rest of the studied wells is characteristic decreasing temperature and declining in the sea level and indicates outer shelf (Abdel-Kirreem, 1983) and open shelf (Sliter, 1972). It is compatible with the propounding of (Keller, 2002) about the ecological tolerance of organisms, which there are two kinds: Ecological Specialists and Ecological Generalists. Also the synchronization of the quondam species with the presence of benthonic foraminifera such as Cibicides, Lagena and Lenticulina with low diversity and small number of individual in particular in some positions at the upper parts of all the studied wells except the well A indicates outer shelf- upper slope (Lianguan Li etal., 1999).

The presence of the Globotruncana and Gansserina in the upper parts of the formation in the well B and lower and middle parts in the rest of the studied wells indicates deep marine (bathyal) ( Pardo et al., 1999).

The conformability of the distinguishing facies from the present study with SMF types 3 and 9 deposited within the FZ 1, 2, 3 suggested basinal, open sea shelf and deep shelf margin as a depositional environments for this formation. 


\section{Summary}

From the evidence presented above the paleoecology of Khasib Formation is characterized by well oxygened (except some positions in the lower parts) in a deep marine environment extend from the middle-outer shelf to the upper slope in the lower and middle parts and shallow marine environment (inner shelf) appeared in some positions in the middle parts. Furthermore the upper parts of the formation exhibits abrupt shallowing due to the tectonic movements during this period. However, the paleoecology of the Tanuma Formation represents the shelf environment; concentrated mainly in the inner and middle shelf; reflecting shallow marine to subbasinal environments which characterized by the anoxic conditions.

The paleoecology of Sa'di Formation represent environmental range extending from basinal to shallow marine which manifested in the middle and outer shelf, fluctuated some times to the upper slope environments; with explicit observation for the tokens of shallowing conditions in the lower parts and relatively in the middle parts at the contact between Early and Late Santonian and likewise at the upper contact of the formation .

A combination of faunal and sedimentological evidences suggest that the paleoecology of Mushorah Formation was characterized by well oxygenated, basin margin, middle and upper slope environments in addition to the middle and outer shelf environment, while the paleoecology documented in Hartha Formation suggests warm, tropical, well oxygenic, shallow marine environment (inner-middle shelf, Rudist bank and lagoon).

Regarding Shiranish Formation, the paleoecology represented by deep marine (upper and middle slope) occasionally turned to outer shelf and sometimes middle shelf such as in the well $\boldsymbol{B}$.

The consequences of paleoecological explanations for different Ostrscode species and other fossils recorded in the studied sections reflect the strong interactions exist between organisms and there environment (in particular depths, salinity and lifestyle) which explain the variations and alterations in the specific morphologies and faunal abundance.

\section{ACKNOWLEDGEMENT}

The authors would like to acknowledge the Mosul university for financial support and providing the research facilities. Also, our thanks are due to the presidency of North Oil Company for providing samples and technical affairs. 


\section{REFERENCES}

Abdel-Kireem, M. R., 1983. A Study of the Paleoecology and Bathymetry of the Foraminiferal Assemblages of the Shiranish Formation (Upper Cretaceous), Northeastern Iraq. Paleogeoqr. , Paleoclimatel. , Paleocol. No. 43, pp. 169-180. Al-Abdul-Razzaq, S., 1983. Biostratiqraphic Zonation of the Ahmadi Formation

(Cretaceous, Kuwait) Using Ostracoda Assemblages. in: Applications of Ostracodes, Proc. 8th Ostracod sump. Houst on, 1982, pp. 394 - 409.

Al- Hamdani, A. M. 1986. Stratigraphic and Geochimestry of Khasib, Tanuma and Sadi Formations.. Unpub. Ph.D thesis, Baghdad Univ., 328 p. [in: Arabic With English Abstract].

Andreu., 1996. Nouvelles Especes D’Osracodes du Turonien Superieur -Coniacien - Santonien de la Region de Boulmane, Moyen Atlas, Maroc. Systematique, Biostratigraphie et Paleoecologie, Paleobiogeographei des Associations. 12e Colloque African deMicropaleontologie, Angers, Elf- quuitaine.

Bandy, O.L.1967. Benthic Foraminifera as Environmental Indices. in:Paleoecology Short Course Lecture Notes. Am. Geol.Inst., pp. 1 - 29.

Benson, R. H., 1972. The Bradleya Problem, with Description of Two New Psychrospheric Ostracode Genera, Agrenocythere and Poseidonamicus (Ostracoda:Crustacea). Smithson. Contr. Paleobiol. No. 33, pp. 1 - 47,4 pls., 11 Figs.

Benson, R. H. 1984, Estimating Greater Paleodepth with Ostracodes. Palaeog. Palaeocl. Palaeoec., No. 48, pp. 187 - 41.

Bonaduce, G., Ciliberto, B., Minichelli, G., Masoli, M. and Pugliese, N., 1983. The Deep Water Benthic Ostracodes of the Mediterranian. In: Maddocks, R. F. (ed.), Applications of Ostracoda. Univ. of Houston Geosc., pp. 459-471, 2Pls.

Brasier, M. D., 1980. Microfossils . George' Allen and Unwin, London, 193 p. Breman, E., 1976. Paleocology and Systematics of Cenomanian and Turonian Ostracoda From Guadalajara and Soria (Central Spain). Rev. Esp. Micropaleon., No. 8, pp. 71 - 122.

Colin, J.P., Lamolda, M.A. and Radriguez Lazaro, J.M., 1982. Los Ostracodos del Vasco Contabrica . Rev. Esp. de Micropol., Vol. 4, Nos. 1,2,3, pp. 187 - 220.

Dingle, R. V., 1981. The Campanian and Maastrichtian Ostracoda of South-East Arica. Ann. S. Afr. Mus. Vol. 85 , No.1, pp. 1 - 181.

Dodd, J. R. and Stanton, R. J, 1988. Paleoecology, Concepts and Applications. A willey Intersci. pub, U.S.A, 559 p.

Duccase, O. and Peypovquet, J. P., 1979. Cenozoic ostracodes, their importance for athymetry, Haydology and Biostratigraphy .in: Montdert, L. Roberts, D. G. et.al. (eds.), Initialre Port of the DSDP, No. 84, pp. 63 - 343.

Elpson, O. 1941. Zur Kenntnis Der Marine Ostracoden Schwedens Mil Besonderer Bervckichtingong Des Skageraks. 2001 Bidr. Uppsala, 1a, pp. 215 - 534.

El-Waer, A. A.,1992. Tertiary and Upper Cretaceous Ostracoda from NW offshore, Liby.Their Taxonomy, Biostratigraphy and Correlation with Taxonomy, 
Biostratigraphy and Correlation With Adjacent Areas. Petrol. Res. Cent. .Special Pub., No.1, 445 p., Pls. 57.

Emery, D. and Myers, K., 1996. Sequence Stratigraphy .Blackwells, U.K. Flügel,

E., 1982. Microfacies Analysis of Limestone. Christenson, K., (Tanslater) Springer- Verlag Berlin, $633 \mathrm{p}$.

Flügel, E., 2004. Microfacies of Carbonate Rocks; Analysis. Interpretation And

Application. (Tanslater) Springer- Verlag Berlin, Heidelberg. 976 p. ,330

Figs., 151 Pls.

Fourcade, E. and Batterline, J. 1988. Reworked and Redeposit Larger Foraminifers on Slopes and in Basins of the Bahamas, leg. 101. Proceedings of the ODP, Scientific Results,Vol. 101, pp. 42 - 61.

Frogley, M. R., Griffiths, H. I. Martens, K., 2002. Modern and Fossils Ostracods From Anicient Lackss. in :The Ostracoda, Aplications in Quaternery Research , Geophysical Monograph. No.131 ,pp. 167-184.

Hammoudi, R. A ,1995. Stratigraphy of the Turonian-Early Campanian Depositional Subcycle From Selected Wells in Iraq. Unpub. Ph.D Thesis, Mosul Univ., 215 p. , [in :Arabic With English Abstract].

Haq, B .U., Hardenbol, J., and Vail P. R., 1987. Chronology of Fluctuating Sea

Levels Since The Triassic. Science. Vol. 235, pp. $1156-1167$.

Harton, D. V., and Droste, H.J., 1988. Mediterranean Deep Sea Ostracods as Legacy of An Early Holocene Anoxic Events. In: Evolutionary Biology of Ostracoda. Procd. $9^{\text {th }}$ Symp. Ostracoda, Schizuoka, Japan, 1985, Dev. Deep Sea-Ostra. pp. 721 - 737.

Henkel, H., 2002. Daignostic Assemblages of Florida Bay and Adjaeent Shallow Water. Comparison USGS, Prof. Paper.

Ishizaki, K. and Kaiho, K., 1990. Japan in Early Cenomenian Times Relative to Tethys And Arctic Waters. Saiti Ho-on Kai Spec .Pub. No. 3, pp. 177 - 189.

Koutsoukos, A. M. and Hart, M. B., 1990. Cretaceous Foraminiferal Morphogroup

Distribution Patterns, Paleocommunities and Trophic Structure : A Case Study

From The Sergio E. Basin , Brazil.-Transactions of The Roual Society of

Edinburgh: Earth Sciences, Vol. 81, pp. 221 - 246.

Koutsoukos, A. M,Mello,M., Filho, N., Hart, M., Maxwell, J., 1991. The Upper Aptian-Albian Succession of The Sergipe Basin Brazil: An Intergrated Paleoenvironmental Assessment, I .Amer. Ass .Petrol. Geol .Bull., Vol. 75 No. 3, pp. 479 - 498.

Kusnetsova, K. I. and Dobrova, M. R., 1997. Middle Jurassic Basins of The Eastern Mediterranean And Their Microbiota (Foraminifera And Ostracoda). Stratigraphy And Geological Correlation, Vol. 5, No. 1, pp. 29 - 37.

Lack, P. S., Palmer, M. A; Biro, P.; Cole, j.; Covich, A. P.; Dahm, C. Gebert, J.; Goddkoop, W.; Martens, K.; Verhoeven, J., 2000. Global Change And The Biodiversity, of Freshwater Ecosystems: Impacts on Between Above Sediment Biota. Bioscience Vol. 50, No. 12, pp. 1099 - 1107. 
Maltz, H., Hofmann, K., Radtke, G. and Cherchi, A.,1985. Biostratigraphy of The Middle Jurassic of NW Sardinia by Means of Ostracods. Senckenbergiana Lethaea, Vol. 66, Nos, 3,4,5, pp. 299 - 345.

Martens, K., 1994. Ostracoda Speciation in Ancient Lakes : A Review-Arch. Hudrobiol. Bein. Ergebn. Limnol. Vol. 11, pp. 22 - 203. in:K.Martens, B. Godderis and G.Coulter (eds.), Speciation in Ancient Lakes.

Martens, K., Waouters, K., Mazepra, G., Schon, I., 2000. Geniation And The Genus Concept in Ancient Lackes. Verh. Internat. Verein. Limnol. Vol. 27, pp. 2640- 2641.

Martens, K., 2001. Ostracoda. In:Guides to The Freshwater Invertebrates of Southern Africa, Vol. 3: Crustacea II, (Cahpter1), INRC Project (Chapter One), Vol. 916, pp. 9 - 77.

Martens, K., 2002. Redundancy And Ecosystem Stability in the Fluctvating Environments of Long Lived Lakes .In: Odada, E. O. and Olago, D. O (eds.), The East African Great Lakees: Imno. Palaeolimno. Biodiv., PP. 309-319.

Monostori, M., 1982. Oligeocene Ostracodes From The Surroundings of Budappest. Ann. Univ. Sci. Budap. Sect. Geol., XXI (1979), pp. 31 - 102, pls. , I-IX.

Monostori, M., 1985. Eocene Osracodes From the Dorog Basin (Northern Transdanubia, Hungary). Akademia Kiado, Budapest, 214 p. pls. .I-XVII.

Pardo, A., Adatte, T., Keller, G. and Oberhansli, H., 1999. Paleoenvironment Changes Across The Cretaceous - Tertiary Boudary at Koshak, Kazakhstan, Based on Planktic Foraminifera in Clay Mineralogy.Palaeogeo. Palaeoclim.Palaeoeco., Vol. 154, pp. 247 - 273.

Park, L. E., Cohen, A. S., Martens, K., 2002 . Ecology And Speciation of The Ostracod Clade (Gomphocythere) Tropical Lake System, Lake Tanganyika, East Africa. Verh. Internat. Verein. Limenol. Vol. 27, pp. 2565- 2669.

Puri, H. S., Bonaduce, G. and Gervasio, A. M., 1969. Distribution of Ostracoda in The Mediterranean .in: J. W. Neale (ed.), The Taxonomy, Morphology And Ecology of The Recent Ostracoda, pp. 356 - 411.

Reyment, R. A.,1980. Observation on The Ostracods of the "Coniacian Transgression" in the Sahara Region. N. Jb. Geol. Paleontol . Mh., Vol.4, pp.252-256.

Rosenfeld, A., Gerry, E. \& Honigstein, A., 1988. Jurassic-Cretaceous Non-Marine

Ostracods From Israel And Palaeoenvironmental Implications. In :Hanai,T., Ikeya, N. and Ishizaki, K. (eds.), Evolutionary Biology of Ostracoda its Fundamentals And Applications. Proc. $9^{\text {th }}$ Int. Symp. Ost., Shizuoka, Japan. July August 1985, Elsevier, pp. 659 - 699.

Rosenfeld, A. and Raab, M., 1974. Cenomanian- Turonian Ostracodes From The Judea Group in Israel (Palestine). Bull. Geol. Surv. Isr., Vol. 62, pp.1 - 64.

Rosenfeld, A. and Raab, M.,1983. Ontogenesis and Stratigraphy of The Ostracod Veeniacytheresis Jezziaeensis (Bischoff, 1969). Jour. Micropaleont., Vol. 21, pp. 56 - 65. 
Schön, I., Verheyen, E. and Martens, K., 2000. Speciation Inaniceint Lake Ostracods : Comparative Analysis of Baikalian Cytherissa And Tanganyikan Cprideis .Verh. Internat. Verein. Limol., Stuttgart, Vol. 27, pp. 2474 - 2677.

Shahin, A. M., 1988. Fossil Fauna And Stable Isotopic Composition Within The Late Cretaceous- Early Tertiary at Gebel Nezzazat, Sinai, Egypt. Unpub. Ph.D. Thesis, Mansoura Univ, 210 p.

Sissingh, W., 1972. Late Cenozoic Ostracoda of The South Aegean Island Arc. Utrecht Micropaleont. Bull. Geol. Inst., Vol. 6, pp. 1 - 187.

Sliter, W.V., 1972. Cretaceous Foraminifers, Depth, Habitats And Their Origin. Nature, Vol. 239 , No. 5374, pp. 5 - 514.

Sliter, W.V., 1985. Cretaceous Redeposited Benthic Foraminifers from DSDP Site 585 in the East Mariana Basin, Western Equatorial Pacific and Implications For The Geologic History of the Region in: Moberly, R., S. Schlanger, et. al., Initial Report of The DSDP, L XXX I X : pp. 327 - 361. Section Jour.

Sliter, W.V., 1989. Biostratigraphic Zonation for Cretaceous Planktonic Foraminifera Examined in Thin Form. Research, Vol. 19, No. 1, pp. 1 - 19.

Sliter, W.V. and Leckie, R.M., 1993. Cretaceous Planktonic Foraminifers and Depositional Environments From The Ontona Java Plateau With Emphasis on Site 803 And 807.-in : Berger, W. H. et. al., (ed.), 1993, Porc. of the Ocean Drillina Program. Scientific Results, Vol. 130, pp. 63 - 84.

Swain, F.M., 1985. Some Ostracoda From The Redessa, Pearsall, Sligo and Upper Hosston Formations (Lower Cretaceous) of Louisiana (U.S.A). Rev. Micropalaeont., Vol. 27, No. 4, pp. 266 - 294.

Szcaechura, J., Abd-Elshafy, E. and Babinot, J.- F., 1991. Late Albian to Early / Mid - Cenomanian Ostracodes From Northern Galala Plateau. Egypt.Acta Palaeont. Polonica, Vol. 36, No.1, pp. 3 - 33.

Van Den Bold, W.A., 1966. Less Ostracodes Du Neogene Gabon.Revue Inst. Fr., Vol. XXI, No. 2, pp. 155 - 189, Pls. 1-4

Van Den Bold, W.A., 1971. Ostracodes Association, Salinity And Depth of Deposition in the Neogene Caribbean Region. Center Rect. Pau. SNPA. Bull. Vol. Supp1., pp. 449- 460, Text-Figs. 1-5.

Van Doninck, K., Schön, I., DeBruyn, L., 2002 . A General Purpose Genotype in An Ancient a Sexual. Oecelogia, Vol. 132, pp. 205 - 212.

Van Morkhoven, F. P. C., 1962. Post- Paleozoic Ostracoda. Elsevier Pub. Comp., Amsterdam, Vol. 1, 204 p.

Van Morkhoven, F.P.C., 1963. Post-Paleozoic Ostracoda. Elsevier Pub .Comp ., Amsterdam, Vol. 2, 478 p. .

Van Morkhoven, F.P.C.M., 1972. Bathymetry of Recent Marine Ostracoda in The North West Gulf of Mexico.- Gulf Coast Assoc. Geol. Soc. Trans. Vol. 22, pp. $241-252$.

Warne, M.T., 1993. Bythocypridiidae (Ostercoda) From the Miocene of The Port Phillip And Western Port Basins, Victoria. Proc. Royal Soc. Victoria, Vol. 102, pp. 105 - 115. 
Wilson, J.L., 1975. Carbonate Facies in Geologic History. Springer and Veralg, $.471 \mathrm{p}$.

Zarrago, E. G. and Lazaro, j.R., 1990. Late Cretaceous Ostracode Fauna from the Biscay Synclinorium (Basque Arc, Northern,Spain). Cour.Forsch.-Inst Senckenberg, Vol. 123, pp. 229 -238.

\section{Explanation of Plate 1}

Fig. 1-Cytherella sp.1 Babinoti et. al., 1988

Carapace [MO.1, UC.1] External left lateral view x 50, Sa'di Formation, $\boldsymbol{B}$ well, depth $908 \mathrm{~m}$.

Fig. 2-Cytherella sp. aff.C.Ubagashi Alexandor, 1932

Carapace [MO.1, UC.2] External left lateral view x 50, Khasib Formation, $\boldsymbol{A}$ well, depth $973 \mathrm{~m}$.

Fig. 3-Cytherella cf. OUM 1110 Grekoff, 1969

Carapace [MO.1, UC.3] External left lateral view x 50, Sa'di Formation $\boldsymbol{B}$ well, depth $910 \mathrm{~m}$.

Fig. 4- Cytherella IRC 22 Grosdidier, 1973

Carapace [MO.1,UC.4] External left lateral view x 50,Mushorah Formation, $\boldsymbol{C}$ well, depth $1766 \mathrm{~m}$.

Fig. 5- Cytherella (C.) Sylvestebradleyi Reyment, 1963

Carapace [MO.1, UC.5] External left lateral view x 50, Hartha Formation, $\boldsymbol{A}$ well, depth $752 \mathrm{~m}$.

Fig. 6- Cytherella IRC6 Grosdidier, 1973

Carapace [MO.1, UC.6] External left lateral view x 50, Khasib Formation, $\boldsymbol{D}$ well, depth $2392 \mathrm{~m}$.

Fig. 7- Cytherella cf. eosulcata Colin, 1973

Carapace [MO.1, UC.7] External right lateral view x 50, Khasib Formation, $\boldsymbol{B}$ well, depth $936 \mathrm{~m}$.

Fig. 8- Cytherella Khalidrazzaqi Al-Abdul-Razzaq, 1981

Carapace [MO.1, UC.8] External left lateral view x 50, Tanuma Formation, $\boldsymbol{C}$ well, depth $2044 \mathrm{~m}$.

Fig. 9- Cytherella mejeri Esker, 1968

Carapace [MO.1, UC.9] External left lateral view x 50, Hartha Formation, $\boldsymbol{C}$ well, depth $1391 \mathrm{~m}$. 
Fig. 10-Cytherlla ovata (Romer) Grekoff, 1953

Carapace [MO.1, UC.10] External left lateral view x 50 , Khasib Formation, $\boldsymbol{C}$ well, depth $2198 \mathrm{~m}$.

Fig. 11-Cytherella sp.1 Colin et. al., 1982

Carapace [MO.1, UC.11] External left lateral view x 50, Sa'di Formation, $\boldsymbol{A}$ well, depth $863 \mathrm{~m}$.

Fig. 12-Cytherella sp.2 Colin et. al., 1982

Carapace [MO.1, UC.12] External left lateral view x 50, Hartha Formation, $\boldsymbol{D}$ well, depth $1612 \mathrm{~m}$.

Fig. 13-Cytherella posterosulcata Al-Abdul al-Razzaa, 1981

Carapace [MO.1, UC.13] External left lateral view x 50, Tanuma Formation, $\boldsymbol{A}$ well, depth $911 \mathrm{~m}$.

Fig. 14- Bairdia IRC19 Grosdidier, 1973 Carapace [MO.1, UC.14] External right lateral view x 40, Hartha Formation, $C$ well, depth $1523 \mathrm{~m}$.

Fig. 15- Bairdia septentrionalis Bonnema, 1941

Carapace[MO.1,UC.15] External right lateral view x 40, Shiranish Formation, B well,depth $834 \mathrm{~m}$.

Fig. 16- Bairdia S.P.C Van den Bold, 1964

Carapace [MO.1,UC.16] External right lateral view x 50, Tanuma Formation, $\boldsymbol{B}$ well, depth 919 m.

Fig. 17- Bythocypris gohrbdonti Esker, 1968

Carapace[MO.1,UC.17]External right lateral view x 50,Mushorah Formation, D well,depth $2026 \mathrm{~m}$.

Fig. 18-Bythocypris windami Butler \& Jones, 1957

Carapace[MO.1,UC.18]External right lateral view x 50,Mushorah Formation, $\boldsymbol{B}$ well, depth $891 \mathrm{~m}$.

Fig. 19- Bythocypris SP.1 Foster et. al., 1983

Carapace [MO.1,UC.19]External right lateral view x 50,Shiranish Formation, $\boldsymbol{A}$ well, depth $583 \mathrm{~m}$.

Fig. 20- Paracypris Jonesi Bonnema,1940

Carapace[MO.1,UC.20] External right lateral view x 50,Shiranish Formation, D well,depth,1256m. 
Fig. 21-Paracypris SP.A Esker,1968

Carapace[MO.1, UC.21]External right lateral view x 50, Mushorah Formation, $\boldsymbol{B}$ well, depth $874 \mathrm{~m}$.

Fig. 22-Paracypris SP.B Esker,1968

Carapace[MO.1,UC.22]External right lateral view x 50,Shiranish Formation, $\boldsymbol{D}$ well, depth, $1316 \mathrm{~m}$.

Fig. 23-Pontocyprella rare El- waer, 1992

Carapace [MO.1, UC.23] External right lateral view x 50, Hartha Formation, B well, depth $851 \mathrm{~m}$.

Fig. 24- Pontocyprella recurva Esker, 1968

Carapace[MO.1,UC.24]External right lateral view x 50,Shiranish Formation, $\boldsymbol{C}$ well, depth, $1167 \mathrm{~m}$.

Fig. 25-Pontocyprella IRD 6 Grosdidier, 1973

Carapace [MO.1,UC.25]External right lateral view x 50, Tanuma Formation, $\boldsymbol{D}$ well, depth,2313 m.

Fig. 26- Pontocyprella IRE 15 Grosdidier, 1973

Carapace [MO.1, UC.26] External right lateral view x 50, Khasib Formation, B well, depth,943 m.

Fig. 27- Propontocypris Sylvesterbradleyi Jain, 1975

Carapace [MO.1, UC.27] External right lateral view x 50, Hartha Formation, D well, depth $1866 \mathrm{~m}$.

Fig. 28-Argilloecia taylorensis Alexande,1935

Carapace [MO.1,UC.28]External right lateral view x 50,Shiranish Formation, $\boldsymbol{C}$ well,depth,1196m.

\section{Explanation of Plate 2}

Fig. 1- Abyssocypris ? Adunce Esker, 1968

Carapace[MO.1,UC.29]External right lateral view x 50,Mushorah Formation, $\boldsymbol{D}$ well,depth,2102m.

Fig. 2-Abyssocypris Tipaca Van der Bold, 1974 
Carapace [MO.1, UC.30] External left lateral view x 50,Shiranish Formation, $\boldsymbol{A}$ well, depth,619 m.

Fig. 3-Paracyprideis IRC 20 Grosdidier, 1973

Carapace[MO.1,UC.31]External right lateral view x 50,Shiranish Formation, $\boldsymbol{C}$ well,depth, $1217 \mathrm{~m}$.

Fig. 4-Schizocythere Salahii El- waer, 1992

[MO.1,UC.32] External right valve lateral view x 50, Shiranish Formation, $\boldsymbol{C}$ well, depth,1156 m.

Fig. 5-Isohabrocythere teiskotensis Apostolescu, 1961

Carapace[MO.1,UC.33]External right lateral view x 50,Shiranish Formation, $\boldsymbol{D}$ well, depth, $1127 \mathrm{~m}$.

Fig. 6 -Brachycythere IRJ 9 Grosdidier, 1973

Carapace [MO.1, UC.34] External left lateral view x 50,Tanuma Formation, $\boldsymbol{C}$ well, depth,2107 m.

Fig. 7-Brachycythere IRE 10 Grosdidier, 1973

Carapace [MO.1, UC.35] External right lateral view x 50, Sa'di Formation, $\boldsymbol{C}$ well, depth,1911 m.

Fig. 8-Brachycythere IRC 28 Grosdidier, 1973

Carapace [MO.1, UC.36] External right lateral view x 50, Sa'di Formation, D well, depth,2189 m.

Fig. 9-Schuleridea babinoti Lazaro, 1988

Carapace [MO.1, UC.37] External right lateral view x 50, Sa'di Formation, $\boldsymbol{A}$ well, depth, $892 \mathrm{~m}$.

Fig. 10-Ovocytheridea cf. Producta Grekoff, 1962

Carapace[MO.1,UC.38] External right lateral view x 50,Tanuma Formation, D well,depth, $2295 \mathrm{~m}$.

Fig. 11-Krithe Sp. M1113 Donze, 1973

Carapace [MO.1, UC.39] External right lateral view x 50, Hartha Formation, B well, depth, $852 \mathrm{~m}$.

Fig. 12-Krithe fortidmophica El-waer, 1992 
Carapace[MO.1,UC.40] External right lateral view x 50,Shiranish Formation, $\boldsymbol{D}$ well,depth, $1327 \mathrm{~m}$.

Fig. 13-Parakrithe lasaensis Lazaro, 1988

Carapace [MO.1, UC.41] External right lateral view x 50,Khasib Formation, $\boldsymbol{D}$ well,depth,2399 m.

Fig. 14-Occultocythereis ishtaria Al- Sheikhly, 1982

Carapace [MO.1, UC.42]External right lateral view x 50, Shiranish Formation, $\boldsymbol{A}$ well,depth,579 m.

Fig. 15-Occultocythereis elongata Al- Sheikhly, 1982

Carapace[MO.1,UC.43] External right lateral view x 50,Shiranish Formation, $\boldsymbol{A}$ well,depth,1263m.

Fig. 16-Ordonia (Ordonia) burmaensis Bassiouni, 1970

Carapace [MO.1,UC.44] External right lateral view x 50,Shiranish Formation, $\boldsymbol{A}$ well,depth, $613 \mathrm{~m}$.

Fig. 17-Holcopocythere bassiporosa Al- Furaih, 1980

Carapace[MO.1,UC.45] External left lateral view x 50,Shiranish Formation, $C$ well, depth, $1319 \mathrm{~m}$.

Fig. 18-Hornibrookella cyclifossata Al- Furaih, 1977

[MO.1, UC.46] External right valve lateral view x 50, Shiranish Formation, $\boldsymbol{A}$ well, depth, $622 \mathrm{~m}$.

Fig. 19-Veenia IRE 8 Grosdidier, 1973

Carapace [MO.1,UC.47] External right lateral view x 50,Tanuma Formation, $\boldsymbol{A}$ well, depth, $924 \mathrm{~m}$.

Fig. 20-Planileberis IRE 23 Grosdidier, 1973

Carapace[MO.1,UC.48] External right lateral view x 50,Mushorah Formation, $\boldsymbol{C}$ well,depth, $1784 \mathrm{~m}$.

Fig. 21-Metacytheropteron berbericus Bassoullet and Damotte, 1969

Carapace [MO.1, UC.49] External right lateral view x 50, Khasib Formation, $\boldsymbol{C}$ well, depth, $2243 \mathrm{~m}$.

Fig. 22-Xestoleberis tunisiensis Esker, 1968

Carapace[MO.1, UC.50]External right lateral view x 50, Shiranish Formation, $\boldsymbol{D}$ well, depth, $1137 \mathrm{~m}$.

Fig. 23-Xestoleberis Sp. Said, 1978

Carapace [MO.1,UC.51] External left lateral view x 50,Shiranish Formation, $\boldsymbol{C}$ well, depth,1242 m.

Fig. 24-Dumontina ? IRE 18 Grosdidier,1973

Carapace [MO.1, UC.52] External left lateral view x 50, Sa'di Formation, $\boldsymbol{C}$ well, depth, $1947 \mathrm{~m}$. 
PLAET- 1

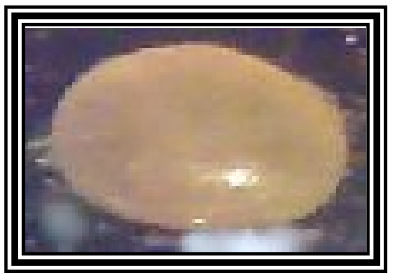

1

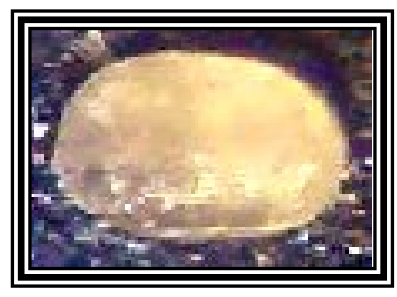

5

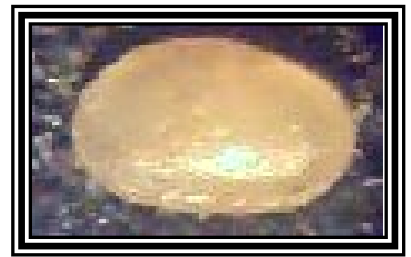

$\mathbf{9}$

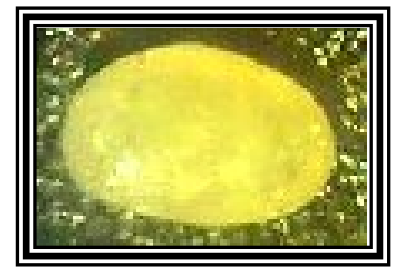

13



17
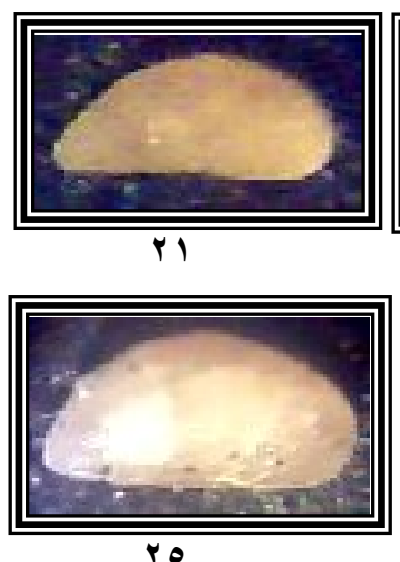

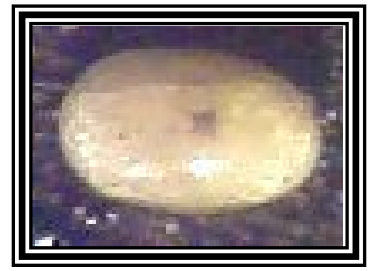

2

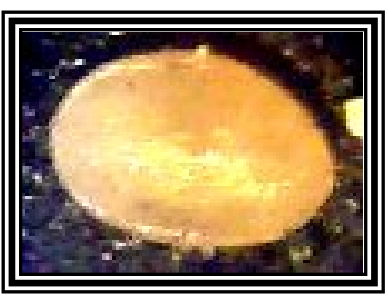

6

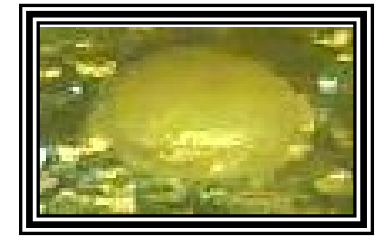

10

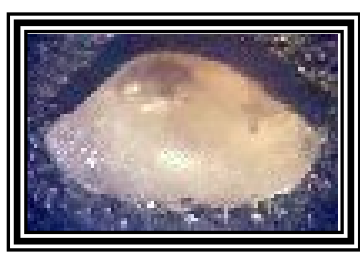

14

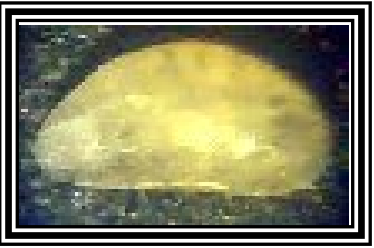

18

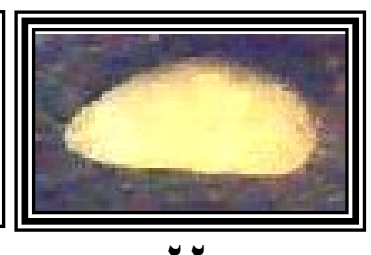

rr



Y 7



3

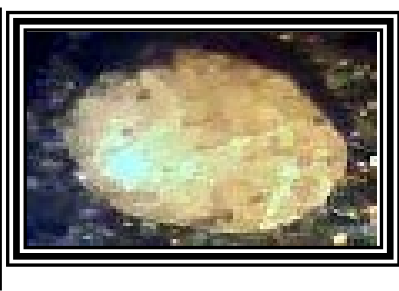

7

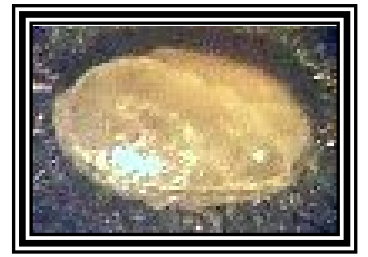

11

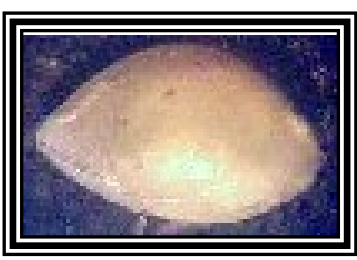

15

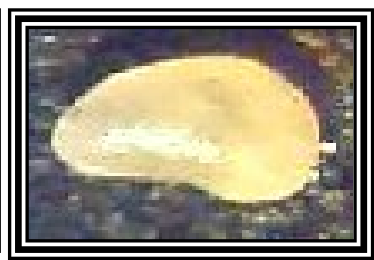

19
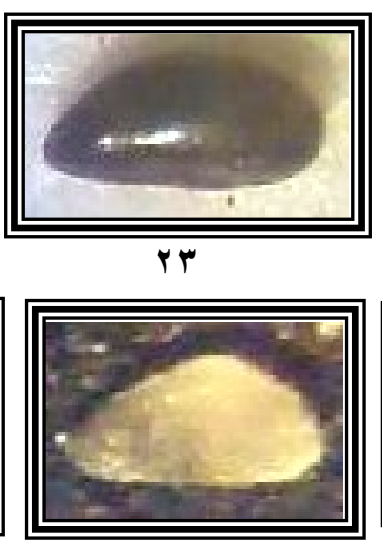

Y V

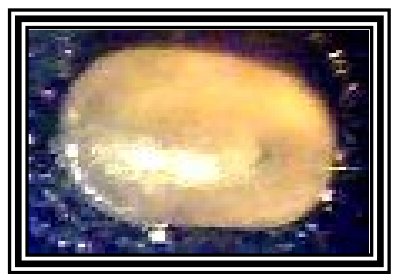

4

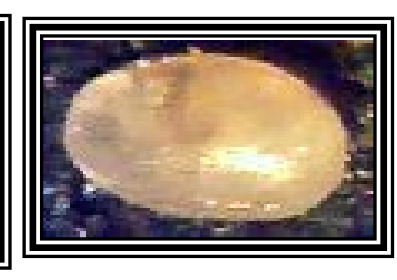

8

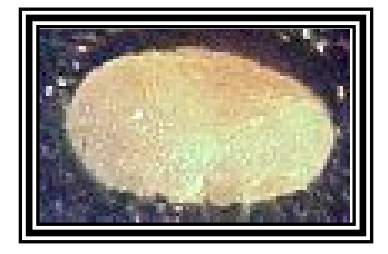

12



16

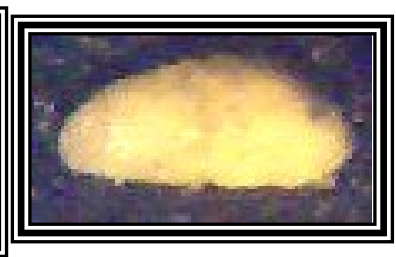

$r$.

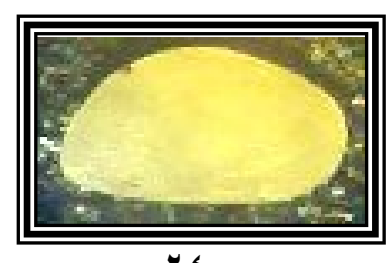

rq




Ibrahim Y. Al-Shareefi et al.,

PLAET- 2

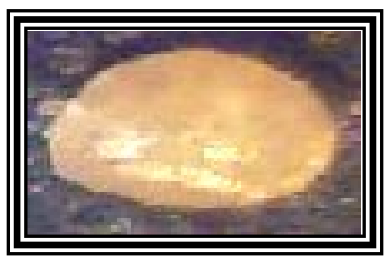

1

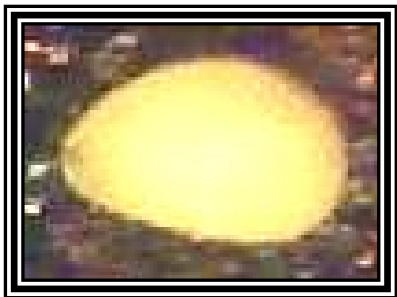

5

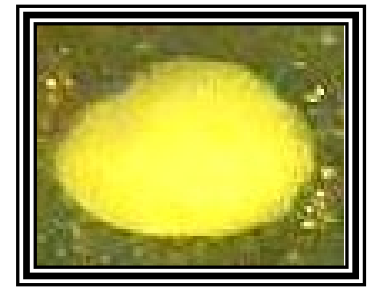

9



ir

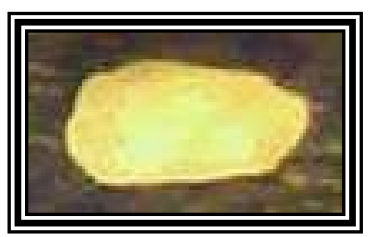

IV

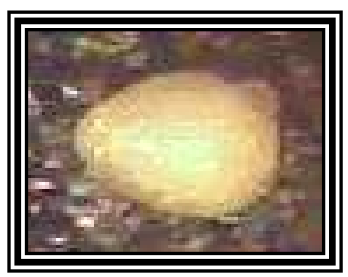

r)



2

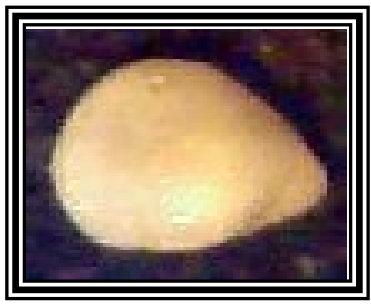

6

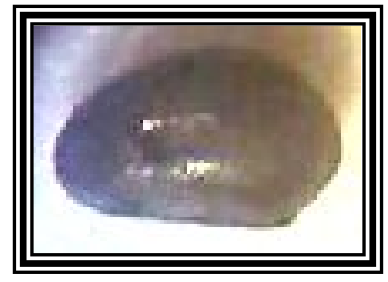

10

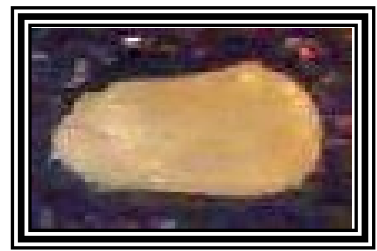

$1 \varepsilon$

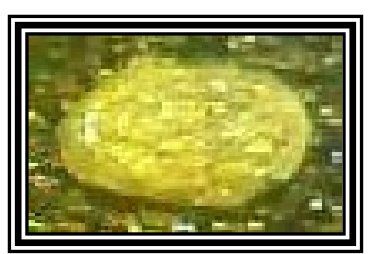

11
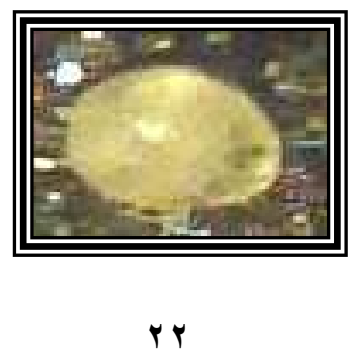

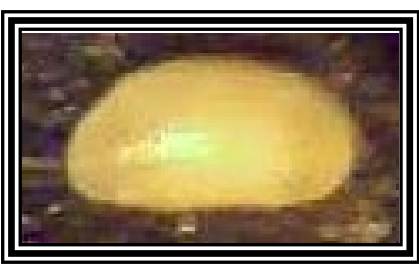

3

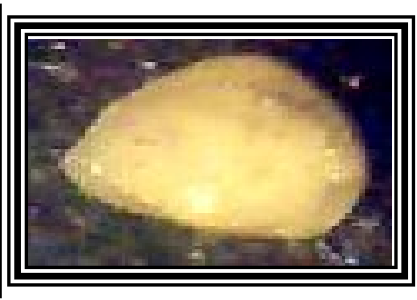

7

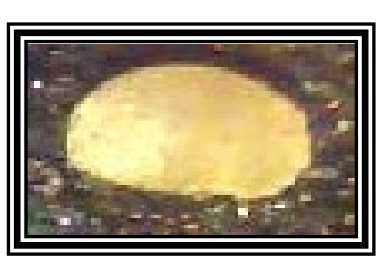

11

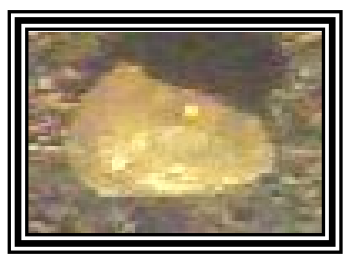

10

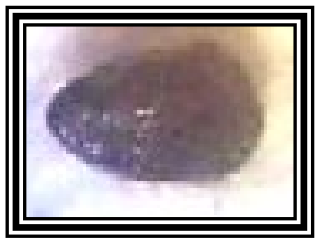

19
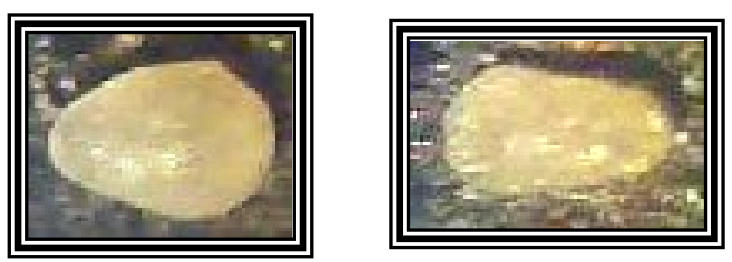

Y 